\title{
Struktur, Unsur, dan Tipe Teks dalam Teks Cerita Fantasi Karya Peserta Didik
}

\author{
Erina Novita ${ }^{1}$, Nursaid ${ }^{2}$ \\ ${ }^{12}$ Fakultas Bahasa dan Seni, Universitas Negeri Padang, Padang \\ *Corresponding author, e-mail: erin.novita15@gmail.com
}

\begin{abstract}
Fantasy story text is one of the narrative texts that contains events or events that happened to a character being told. The series of events has a plot that starts from orientation, complications, to resolution. Fantasy stories actually also feature realistic events and actions, but there are also things that are hard to accept. Even so, the overall development of the storyline is still subject to the law of cause and effect or the law of the plot that applies in writing that is generally agreed upon. This study aims to determine the tendency of students in making fantasy story texts and this research focuses on elements, structures, and types in fantasy story texts. This research uses qualitative research with descriptive method. The results obtained are that students tend to make fantasy story texts based on examples that have been given. In addition, the structure used tends to be incomplete. In the orientation section is often not used. The type of fantasy story text used tends to cross time. The written message tends to be implicit.
\end{abstract}

Keywords: Element, Fantasy Story Text, Structure, Type

Received December 6, 2021

Revised January 31, 2022

Published February 2, 2022

This is an open access article distributed under the Creative Commons 4.0 Attribution License, which permits unrestricted use, distribution, and reproduction in any medium, provided the original work is properly cited. (C2018 by author.

\section{Pendahuluan}

Pembelajaran Bahasa Indonesia berbasis teks mulai diperkenalkan pada Kurikulum 2013. Kurikulum 2013 mulai memperkenalkan pembelajaran Bahasa Indonesia menggunakan teks atau genre. Pembelajaran berbasis teks ini didasari sang ahli Linguistik Fungsional Sistemik (LFS). Pembelajaran ini lebih menekankan dalam pendekatan ilmiah atau scientific approach dan evaluasi otentik. Selain itu, pembelajaran teks dilaksanakan sedikit demi sedikit sebagai berikut. Pertama, menciptakan konteks. Kedua, menaruh pemodelan. Ketiga, menyusun teks secara berkelompok. Keempat, menyusun teks secara mandiri. (Kemendikbud, 2013). Berdasarkan pelaksanaan tersebut, peserta didik memerlukan empat keterampilan, yaitu keterampilan menyimak, keterampilan berbicara, keterampilan membaca, dan keterampilan menulis. Terfokus pada keterampilan menulis, pembelajaran keterampilan menulis merupakan gabungan unsur teori dan kebiasaan yang tingkat keberhasilannya ditentukan oleh individu itu sendiri. Oleh sebab itu, peserta didik akan berhasil menguasai keterampilan menulis apabila ia sudah mempelajari teori yang sudah ada dan menjadikan membaca sebagai sebuah kebiasaan dalam menambah kosakata ketika menulis.

Berdampingan dengan hal tersebut, salah satu keterampilan menulis yang dipelajari peserta didik tingkat SMP kelas VII semester I adalah teks cerita fantasi. Pembelajaran keterampilan menulis teks cerita fantasi terdapat di dalam unsur Kompetensi Dasar (KD) 3.4-4.4 yang berbunyi, "Menelaah struktur dan kebahasaan teks cerita fantasi yang dibaca dan didengar, menyajikan gagasan kreatif pada bentuk cerita fantasi secara ekspresi dan tulis menggunakan dan memperhatikan struktur serta penggunaan bahasa" dalam buku cetak peserta didik karya Harsiati, Trianto, dan Kosasih (2017). Di samping itu, pembelajaran teks cerita fantasi juga dapat mengembangkan kognitif peserta didik. Hal ini sesuai dengan penelitian yang dilakukan oleh Fajria (2017) yang menyimpulkan bahwa teks cerita fantasi termasuk salah satu bentuk teks narasi yang merupakan materi yang terdapat pada kurikulum 2013 edisi revisi. Sejalan dengan penelitian Jumesa, Abdurahman, dan Emidar (2018), cerita 
fantasi merupakan salah satu teks narasi yang berisikan peristiwa atau kejadian yang menimpa seorang tokoh yang diceritakan. Rangkaian peristiwa tersebut memiliki alur yang dimulai dari orientasi, komplikasi, sampai resolusi. Selain itu, Nurgiyantoro (2018) mengemukakan bahwa cerita fantasi sebagai cerita yang menampilkan tokoh, alur, atau tema yang derajat kebenarannya masih diragukan, baik secara keseluruhan maupun hanya sebagian cerita. Cerita fantasi sebenarnya juga menampilkan peristiwa dan aksi yang realistik, tetapi di dalamnya juga terdapat sesuatu yang sukar diterima. Misalnya, cerita tentang kehidupan manusia kerdil yang hidup secara kelompok dan memiliki kebiasaan hidup seperti manusia normal, baik menyangkut kebutuhan fisik, batin, maupun spiritual, tetapi kebenaran cerita itu sendiri masih diragukan. Uraian tersebut sejalan dengan penelitian yang pernah dilakukan oleh Putri, Thahar, dan Arief (2018), pengetahuan tentang kebahasaan, kosakata, dan imajinasi atau berpikir secara kreatif itu sangat dibutuhkan. Teks cerita fantasi yang bagus tidak hanya bisa menumbuhkan rasa ketidakpercayaan, melainkan juga membuat pembaca percaya dan yakin kalau cerita tersebut benar terjadi. Hal tersebut bisa terjadi karena teks cerita fantasi memiliki bagian-bagian yang sebenarnya masuk akal dan logis, hanya saja campur aduk dengan sesuatu yang tidak masuk akal. Hal ini sesuai dengan penelitian yang dilakukan oleh Gunawan (2016) yang menemukan fakta di lapangan, bahwa siswa sebetulnya tertarik dengan pembelajaran sastra. Namun, untuk terus meningkatkan minat baca dan antusiasme siswa dalam mempelajari teks cerita fantasi perlu adanya penambahan kedalaman materi dan penyajian contoh teks cerita fantasi yang lebih baru sehingga dapat dicapai tujuan pembelajaran yang diharapkan.

Meskipun begitu, keseluruhan pengembangan alur cerita tetap saja tunduk pada hukum sebab-akibat atau The law of the plot yang berlaku dalam penulisan yang disepakati secara umum. Hal itulah yang menjadikan cerita fantasi menjadi kuat karena dapat dipertanggungjawabkan secara instrinsik. Menurut Harsiati, Trianto, dan Kosasih (2016), teks cerita fantasi punya tiga struktur bagian. Pertama, orientasi, pada tahap ini pengarang mengungkapkan pengenalan tokoh pada latar cerita. Pengenalan tokoh disangkut-pautkan dengan pengenalan pelaku (terutama pelaku utama). Kedua, munculnya komplikasi akibat adanya konflik. Tahap-tahap umum penjalinan konflik dalam cerita fantasi dimulai dari munculnya konflik, peningkatan konflik hingga konflik memuncak (klimaks). Ketiga, resolusi adalah suatu keadaan ketika konflik terpecahkan dan menemukan penyelesaiannya. Pada tahap ini, pengarang berupaya mengungkapkan solusi dari berbagai semua konflik yang dialami oleh tokoh utama atau para tokoh yang diceritakan.

Selain struktur, teks cerita fantasi juga memiliki unsur pembangun. Unsur pembangun yang terdapat dalam teks cerita fantasi tidak jauh berbeda dengan unsur pembangun cerita pada umumnya. Pada teks cerita fantasi, fokusnya yaitu unsur intrinsik. Menurut Setiyaningsih dan Santhi (2019), unsur intrinsik ialah unsur pembangun karya itu sendiri. Pertama, dalam penulisan teks cerita fantasi tentu menentukan tema yang akan diangkatkan. Tema merupakan sebuah gagasan utama yang diungkapkan oleh pengarang dalam sebuah cerita. Tema menjadi pokok permasalahan yang menjadi titik penyusunan sebuah cerita. Kedua, unsur pembangun cerita yaitu alur/plot. Alur adalah jalan cerita secara kronologis. Sedangkan plot adalah alur cerita yang bersifat sebab akibat atau bentuk pengembangan dari alur. Alur terdiri atas tiga bagian, yaitu alur konvensional, non-konvensional, dan campuran. Ketiga, dalam cerita fantasi juga terdapat tokoh dan penokohan. Tokoh sebutan untuk pelaku dalam sebuah cerita. Sedangkan, penokohan adalah penggambaran karakter dari tokoh yang diceritakan. Keempat, selain tiga hal yang telah dibahas, teks cerita fantasi mempunyai latar di mana cerita itu terjadi. Latar atau setting merupakan kesatuan tempat, waktu, dan suasana yang menjadi wadah tokoh yang terlibat dalam peristiwa tersebut. Latar juga menjadi tempat dan urutan waktu ketika suatu tindakan berlangsung. Kelima, sudut pandang. Cara pandang yang ingin disampaikan pengarang sebagai sarana untuk menyajikan tokoh, tindakan, latar, dan berbagai peristiwa yang memaparkan cerita. Bentuk pembagian sudut pandang tokoh cerita dari pengarang, yaitu (1) sudut pandang orang pertama, (2) sudut pandang orang ketiga, dan (3) sudut pandang campuran. Ketujuh, amanat adalah pesan yang ingin disampaikan dalam sebuah cerita baik secara implisit maupun eksplisit. 
Selain struktur dan unsur, teks cerita fantasi juga mempunyai tipe. Tipe teks cerita fantasi menurut Asih (2019) terbagi dua. Pertama, tipe teks cerita fantasi berdasarkan kesesuaiannya dengan dunia nyata dan berdasarkan latar cerita. Berdasarkan kehidupan ada yang sesuai dengan dunia nyata dan irisan sebagian ceritanya pernah terjadi di dunia nyata dan sebagian lagi hanya khayalan atau bumbu cerita dari pengarang. Kedua, berdasarkan latar cerita dibedakan menjadi dua, yaitu (1) masa sekarang dan masa lampau dan (2) masa sekarang dan futuristik. Beberapa pendapat tersebut disimpulkan teks cerita fantasi salah satu teks narasi yang berisi tentang cerita dengan menampilkan tokoh, alur, atau tema yang berkisah suatu peristiwa atau kejadian yang berkaitan dengan teknologi dan tidak mungkin bisa terjadi. Teks cerita fantasi bersifat imajinatif dan menjadi daya tarik tersendiri bagi pembaca agar bisa merasakan kejadian yang realistik. Namun, di dalamnya masih terdapat sesuatu yang mungkin sulit untuk diterima.

Dilihat dari hasil wawancara dengan guru mata pelajaran Bahasa Indonesia kelas VII SMP Negeri 7 Padang, Mindawati, M.Pd., pada tanggal 11 September 2021 dapat dilihat pada beberapa aspek sebagai berikut. Pertama, peserta didik memiliki semangat dan senang dalam pembelajaran teks cerita fantasi. Kedua, dalam proses memproduksi teks cerita fantasi, peserta didik belum mampu menentukan latar lintas ruang dan waktu dalam penulisan teks tersebut. Ketiga, adanya kesulitan dalam penggunaan gaya bahasa (majas) dalam proses memproduksi cerita fantasi. Keempat, masih kurang tepat dalam menempatkan struktur teks pada teks cerita fantasi yang dibuat. Kelima, kurangnya variasi tipe teks cerita yang dibuat oleh peserta didik. Hal ini memperlihatkan bahwa peserta didik kurang mampu mengembangkan teks cerita fantasi berdasarkan metode yang ada.

Berdasarkan uraian permasalahan dari hasil wawancara tersebut tentang struktur, unsur, dan tipe teks cerita fantasi yang ditulis peserta didik penting untuk diteliti karena SMP Negeri 7 Padang termasuk sekolah favorit di Kota Padang. Hal ini dibuktikan dengan banyaknya prestasi yang dicapai, baik dalam bidang akademik maupun nonakademik. Salah satunya dalam bidang bahasa, SMP Negeri 7 Padang mendapatkan beberapa gelar juara dalam lomba mendongeng dan baca puisi tingkat SMP se-Kota Padang pada tahun 2019. Menerbitkan majalah Senjozen sekali dua tahun yang diisi oleh karya-karya peserta didik dan di dalamnya terdapat teks cerita fantasi. Selain itu, SMP Negeri 7 Padang juga sudah menerapkan Kurikulum 2013 dan belum pernah dilakukan penelitian mengenai struktur, unsur, dan tipe teks cerita fantasi. Dipilihnya kelas VII menjadi objek penelitian karena teks cerita fantasi dipelajari di kelas VII semester I. Dengan demikian, penelitian ini diharapkan mampu memberikan informasi terkait struktur, unsur, dan tipe teks khususnya dalam pembelajaran teks cerita fantasi peserta didik kelas VII SMP Negeri 7 Padang.

Penelitian ini difokuskan pada struktur, unsur, dan tipe teks cerita fantasi yang ditulis oleh peserta didik. Tujuan penelitian ini, yaitu (1) mendeskripsikan struktur teks (orientasi, komplikasi, resolusi), (2) unsur, dan (3) tipe teks yang terdapat di dalam teks cerita fantasi karya peserta didik. Penelitian ini diharapkan dapat bermanfaat baik secara teoritis maupun praktis. Manfaat teoritis berkaitan dengan khazanah ilmu pengetahuan, yaitu menambah referensi penjabaran dan teori-teori terutama yang berkaitan dengan teks cerita fantasi.

Sebelum penelitian ini dilaksanakan, telah pernah dilakukan penelitian terhadap teks yang dikemukakan pada penelitian ini. Penelitian yang relevan tersebut dilakukan Pertama, Fandini (2018) melakukan penelitian yang berjudul "Penguasaan Struktur Teks dan Unsur Kebahasaan Cerita Fantasi Peserta didik Kelas VII A SMP Negeri 3 Wonomulyo Kabupaten Polewali Mandar". Hasil penelitian yang diperoleh menunjukkan bahwa penguasaan struktur teks dan unsur kebahasaan cerita fantasi peserta didik bervariasi atau berbeda-beda. Hal ini ditunjukkan dari jawaban peserta didik dalam menentukan struktur teks dan unsur kebahasaan cerita fantasi yang telah dibagikan. Perbedaan pada penelitian ini terletak pada unsur dan tipe dari teks cerita fantasi. Kedua hasil yang didapatkan oleh Fandini (2018) penguasaan peserta didik terhadap struktur dan unsur kebahasaan dalam teks cerita fantasi. Sedangkan dalam penelitian ini hasil yang akan didapatkan yaitu kecenderungan dalam menulis teks cerita fantasi oleh peserta didik. 
Kedua. Mustika, Nursaid, dan Ena (2018) melakukan penelitian tentang "Struktur, Diksi, dan Kalimat dalam Teks Cerita Fantasi Karya Peserta didik Kelas VII SMP Negeri 27 Padang". Hasil yang didapatkan, yaitu Pertama, dalam menulis teks-teks cerita fantasi, peserta didik kelas VII SMP Negeri 27 Padang telah menggunakan ketiga struktur teks cerita fantasi. Ketiga struktur teks cerita fantasi tersebut, yaitu orientasi, komplikasi, dan resolusi. Jika dilihat secara umum, dalam membuat teks cerita fantasi peserta didik kelas VII SMP Negeri 27 Padang telah menggunakan ketiga struktur tersebut. Hal itu terbukti dari dua puluh lima teks cerita fantasi yang telah dianalisis, terdapat dua puluh satu teks cerita fantasi yang lengkap menggunakan orientasi, komplikasi, dan resolusi. Akan tetapi, masih ada beberapa orientasi, komplikasi, dan resolusi yang ditulis kurang tepat dengan struktur yang ditulis peserta didik pada teks. Namun, isinya sudah menunjukkan keseluruhan karakteristik dari masing-masing bagian struktur tersebut. Kedua, jika dilihat dari penggunaan diksi secara umum peserta didik kelas VII SMP Negeri 27 Padang telah menggunakan diksi dengan tepat. Hal itu terlihat dari 25 data teks cerita fantasi karya peserta didik yang dianalis masingmasing dari teks tersebut telah menggunakan pilihan kata yang mampu menarik perhatian pembaca. Ketiga, jika dilihat dari penggunaan kalimat dalam teks cerita fantasi yaitu penggunaan kalimat langsung dan kalimat tidak langsung. Peserta didik kelas VII SMP Negeri 27 Padang telah menggunakan kedua jenis kalimat tersebut. Secara umum, penggunaan kalimat yang dominan digunakan peserta didik kelas VII SMP Negeri 27 Padang adalah kalimat tidak langsung. Jika dilihat dari segi struktur kaidah kalimat sudah tepat hanya saja penggunaan ejaan yang belum tepat. Dari segi struktur penulisan kalimat langsung masih terdapat kesalahan dalam penggunaan tanda petik sehingga kalimat langsung yang ditulis menjadi tidak tepat. Hal ini berarti bahwa penguasaan peserta didik kelas VII SMP Negeri 27 Padang dalam menggunakan kalimat lebih menguasai penggunaan kalimat tidak langsung. Sedangkan penggunaan kalimat langsung lebih diperlukan dalam menulis teks cerita fantasi untuk membangun sebuah dialog dalam konflik yang diceritakan.

Perbedaan dua penelitian ini terletak pada subjek penelitian. Selain struktur teks, Mustika, Nursaid, dan Ena (2018) meneliti diksi dan kalimat dari teks cerita fantasi. Kemudian dari segi hasil, hasil yang didapatkan berupa penulisan teks cerita fantasi, penggunaan diksi, dan penggunaan kalimat. Sedangkan, pada penelitian ini tentang unsur dan tipe dalam teks cerita fantasi dan dari segi hasil berupa kecenderungan hasil tulisan peserta didik.

Ketiga, Hartendi (2019) melakukan penelitian tentang "Struktur dan Kebahasaan Teks Cerita Fantasi Karya Peserta didik Kelas VII SMP Negeri 5 Rambah Hilir, Kabupaten Rokan Hulu, Provinsi Riau". Hasil penelitian menunjukkan hal-hal sebagai berikut. Pertama, dalam menulis teks cerita fantasi peserta didik kelas VII SMP Negeri 5 Rambah Hilir, Kabupaten Rokan Hulu, Provinsi Riau telah menggunakan ketiga struktur teks cerita fantasi. ketiga struktur teks cerita fantasi tersebut, yaitu orientasi, komplikasi, dan resolusi. Hal itu terbukti dari 30 teks cerita fantasi yang dianalisis, terdapat 28 teks cerita fantasi memiliki struktur yang lengkap. Kedua, jika dilihat dari kebahasaan ditemukan enam belas jenis majas di dalam karya peserta didik kelas VII SMP Negeri 5 Rambah Hilir, Kabupaten Rokan Hulu, Provinsi Riau dan 422 ketepatan penggunaan kata hubung (konjungsi) di dalam karya peserta didik kelas VII SMP Negeri 5 Rambah Hilir, Kabupaten Rokan Hulu, Provinsi Riau.

Perbedaan dua penelitian ini terletak pada subjek penelitian. Selain struktur teks, Hartendi (2019) meneliti unsur kebahasaan dari teks cerita fantasi. Selain itu, penelitian ini juga meneliti penggunaan dari struktur dan kebahasaan dari teks cerita fantasi yang ditulis oleh peserta didik. Sedangkan, pada penelitian ini tentang unsur dan tipe dalam teks cerita fantasi. Hasil yang didapatkan penelitian ini melihat kecenderungan dari struktur, unsur, dan tipe dalam teks cerita fantasi yang ditulis oleh peserta didik.

\section{Tinjauan Kepustakaan}

Harsiati, Trianto, dan Kosasih (2016) mengemukakan bahwa teks cerita fantasi merupakan salah satu genre cerita fiksi yang sangat penting untuk melatih kreativitas. Fantasi sendiri dapat terbagi menjadi dua, yaitu fantasi aktif dan fantasi pasif. Fantasi aktif adalah fantasi yang dikendalikan oleh pikiran dan kemauan. Berfantasi secara aktif bisa mengasah kreativitas. Contohnya seorang perancang, pelukis, dan penulis. Sebaliknya, fantasi pasif 
yaitu fantasi yang tidak dikendalikan, seolah-olah orang yang berfantasi hanya pasif sebagai wadah tanggapan-tanggapan. Contohnya seseorang yang melamun.

Menurut Taum (2017), cerita fantasi adalah cerita fiksi bergenre fantasi (imajinatif) yang berkisah hal yang tidak mungkin dapat terjadi. Cerita fantasi bukan hanya berkisah mengenai tokoh-tokoh supranatural yang lazim muncul pada cerita masa lalu, tetapi juga dapat melibatkan tokoh dan kehidupan modern. Dalam hal demikian, cerita fantasi dapat dipandang sebagai sesuatu yang mengandung komentar metaforis terhadap kehidupan sosial dewasa ini. Fiksi fantasi yang mengangkat berbagai isu dalam kehidupan modern, realitas kehidupan masa kini mencerminkan realitas, juga menampilkan hal-hal yang tidak masuk akal, terlihat familiar, dan banyak digemari pembaca. Bahkan, novel Harry Potter yang menjadi best seller dunia itu pun sebenarnya mencampuradukkan antara realitas kehidupan modern dan cerita-cerita lain yang sulit dipercaya. Namun, semuanya dijalin dengan alur yang bersebab-akibat (kausalitas) sehingga seolah-olah semuanya menjadi masuk akal.

Menurut Putri, Thahar, dan Arief (2018), teks cerita fantasi adalah salah satu bentuk kegiatan nonilmiah. Menulis teks cerita fantasi juga membutuhkan pengetahuan tentang kekayaan kebahasaan dan kosakata di samping berimajinasi atau berpikir kreatif. Teks fantasi yang bagus tidak hanya mampu menangguhkan rasa ketidakpercayaan, melainkan agar dapat membuat pembacanya percaya dan meyakini cerita tersebut benar-benar ada di dunia nyata. Hal tersebut dikarenakan dalam sebuah teks cerita fantasi ada bagian-bagian tertentu yang sebenarnya masuk akal, logis, hanya saja hal-hal itu kemudian dicampuradukkan dengan sesuatu yang tidak masuk akal. Namun demikian, secara keseluruhan pengembangan alur cerita tetap saja tunduk pada hukum sebab-akibat, tunduk pada The law of the plot yang berlaku dalam penulisan cerita konvensional. Hal itulah yang menyebabkan cerita fantasi menjadi kuat dan meyakinkan karena dapat dipertanggungjawabkan secara instrinsik.

\section{Metode}

Jenis penelitian ini adalah kualitatif dengan metode deskriptif. Dengan metode yang digunakan adalah metode deskriptif. Penelitian ini digunakan untuk menganalisis tulisan peserta didik dengan tujuan mendeskripsikan struktur, unsur, dan tipe pada teks cerita fantasi yang ditulis oleh peserta didik. Sumber data penelitian ini adalah hasil dokumentasi teks cerita fantasi berupa tulisan peserta didik. Jumlah tulisan tersebut sebanyak 48 teks. Teknik pengumpulan data dalam penelitian ini dilakukan melalui tiga tahap. Pertama, peneliti membaca dan memahami teks cerita fantasi yang ditulis peserta didik. Kedua, peneliti menandai bagian-bagian yang berkaitan dengan struktur, unsur, dan tipe teks cerita fantasi. Ketiga, menginventarisasi data yang berkaitan dengan struktur, unsur, dan tipe teks ke dalam format inventarisasi data. Tahap penganalisisan data dalam penelitian ini adalah sebagai berikut. Pertama, mengidentifikasi unsur umum data. Kedua, mengidentifikasi data berdasarkan teori yang menjadi acuan. Identifikasi data dilakukan dengan cara membuat format identifikasi struktur, unsur, dan tipe teks cerita fantasi. Ketiga, menganalisis data. Keempat, menginterpretasi data yang sudah dianalisis. Kelima, menyimpulkan hasil deskripsi data dengan menulis laporan.

\section{Hasil Penelitian dan Pembahasan}

\section{Hasil Penelitian}

Berdasarkan penelitian yang dilakukan pada teks cerita fantasi karya peserta didik kelas VII SMP Negeri Padang ditemukan tiga struktur teks cerita fantasi, yakni orientasi, komplikasi, dan resolusi. Keseluruhan teks cerita fantasi karya peserta didik kelas VII SMPNegeri 7 Padang yang diteliti, ditemukan 48 teks cerita fantasi yang memiliki struktur orientasi, 48 teks cerita fantasi yang memiliki struktur komplikasi, dan 46 teks cerita fantasi yang memiliki struktur resolusi. Jadi, secara umum peserta didik kelas VII SMP Negeri 7 Padang telah menggunakan ketiga struktur teks cerita fantasi. Hal ini terbukti dari 48 teks cerita fantasi yang dianalisis terdapat 46 teks cerita fantasi yang memiliki struktur lengkap, yaitu orientasi, komplikasi, dan resolusi. Agar lebih jelas dapat dilihat pada tabel berikut. 
Tabel 1. Struktur Teks Cerita Fantasi Karya Peserta didik Kelas VII SMP Negeri 7 Padang

\begin{tabular}{lll}
\hline No. & Struktur Teks Cerita Fantasi & Jumlah Teks \\
\hline 1. & Orientasi & 48 \\
2. & Komplikasi & 48 \\
3. & Resolusi & 46
\end{tabular}

Sumber: Hasil Olahan Peneliti tahun 2021

Di samping itu, temuan hasil analisis unsur teks cerita fantasi berdasarkan unsur-unsur intrinsik teks cerita fantasi. Unsur teks cerita fantasi, yakni tema, alur, tokoh dan penokohan, latar, sudut pandang, dan amanat. Keseluruhan teks cerita fantasi karya peserta didik kelas VII SMP Negeri 7 Padang yang diteliti, ditemukan 3 teks yang menggunakan tema futuristik, 6 teks yang menggunakan tema magic, dan 39 teks yang menggunakan tema supranatural. Teks yang menggunakan alur maju terdapat 48 teks, sedangkan alur mundur dan campuran tidak ada yang menggunakannya. Tokoh dan penokohan pada teks cerita fantasi karya peserta didik menggunakan metode analitik sebanyak 14 teks, sedangkan metode dramatik sebanyak 34 teks. Selanjutnya, latar yang digunakan sudah menggambarkan latar tempat, suasana dan juga waktu yang sedang terjadi, sehingga karya peserta didik ini di bagian latar sudah lengkap. Sudut pandang orang pertama terdapat 1 teks, sudut orang ketiga terdapat 47 teks, sedangkan sudut pandang campuran tidak ada yang menggunakan. Terakhir amanat, terdapat 13 teks yang menggunakan secara implisit dan 35 teks secara eksplisit. Jadi, secara umum peserta didik kelas VII SMP Negeri 7 Padang telah menggunakan keenam unsur teks cerita fantasi. Hal ini terbukti dari 48 teks cerita fantasi yang dianalisis semuanya memiliki unsur yang lengkap, yaitu tema, alur, tokoh dan penokohan, latar, sudut pandang, dan amanat. Agar lebih jelas dapat dilihat pada tabel berikut.

Tabel 2. Unsur Teks Cerita Fantasi Karya Peserta didik Kelas VII SMP Negeri 7 Padang

\begin{tabular}{clll}
\hline No. & Unsur Teks Cerita Fantasi & Jumlah Teks \\
\hline \multirow{2}{*}{ 1. } & \multirow{2}{*}{ Tema } & Futuristik & 3 \\
& & Magis & 6 \\
& & Supernatural & 39 \\
2. & Alur & Maju & 48 \\
& & Mundur & 0 \\
& Tokoh & Campuran & 0 \\
3. & Penokohan & Analitik & 48 \\
& & Dramatik & 14 \\
& & Tempat & 34 \\
4. & Latar & Waktu & 48 \\
& & Suasana & 48 \\
& & Orang Pertama & 48 \\
5. & Sudut Pandang & Orang Ketiga & 1 \\
& & Campuran & 47 \\
6. & Amanat & Implisit & 0 \\
& & Eksplisit & 13 \\
& & & 35 \\
\hline
\end{tabular}

Sumber: Hasil Olahan Peneliti tahun 2021

Demikian juga, ditemukan dua tipe teks cerita fantasi, yaitu berdasarkan kesesuaian dengan kehidupan nyata dan berdasarkan latar cerita. Berdasarkan kesesuaian dengan kehidupan nyata, ditemukan teks cerita fantasi karya peserta didik tipe fantasi total sebanyak 1 teks, sedangkan teks cerita fantasi tipe fantasi irisan sebanyak 47 teks. Berdasarkan latar cerita, ditemukan teks cerita fantasi karya peserta didik tipe sezaman sebanyak 17 teks, 
sedangkan teks cerita fantasi tipe lintas waktu sebanyak 31 teks. Jadi, secara umum peserta didik kelas VII SMP Negeri 7 Padang telah menggunakan kedua tipe teks cerita fantasi. Hal ini terbukti dari 48 teks cerita fantasi yang dianalisis semuanya termasuk ke dalam tipe teks yang tepat.Agar lebih jelas dapat dilihat pada tabel berikut.

Tabel 3. Tipe Teks Cerita Fantasi Karya Peserta didik Kelas VII SMP Negeri 7 Padang

\begin{tabular}{cccc}
\hline No. & Tipe Teks Cerita Fantasi & Jumlah Teks \\
\hline 1. Berdasarkan Kesesuaian & Fantasi Total & & 1 \\
dengan Kehidupan Nyata & Fantasi Irisan & & 47 \\
& & Masa Lampau & 5 \\
& Sezaman & Masa Kini & 11 \\
& & Futuristik & 1 \\
2. Berdasarkan Latar Cerita & & Masa Kini dan & 26 \\
& Lintas & Masa Lampau & 5 \\
& Waktu & Masa Kini dan & \\
& & Futuristik &
\end{tabular}

Sumber: Hasil Olahan Peneliti tahun 2021

Pembahasan dilakukan berdasarkan tujuan penelitian, yaitu untuk mendeskripsikan (1) struktur dalam teks cerita fantasi karya peserta didik kelas VII SMP Negeri Padang, (2) unsur dalam teks cerita fantasi karya peserta didik kelas VII SMP Negeri 7 Padang, dan (3) tipe dalam teks cerita fantasi karya peserta didik kelas VII SMP Negeri 7 Padang. Berikut pembahasan ketiga hal tersebut.

\section{Pembahasan}

\section{Analisis dari Segi Struktur Teks Cerita Fantasi}

Berdasarkan temuan yang dilakukan dapat disimpulkan bahwa secara umum teks cerita fantasi yang ditulis peserta didik kelas VII SMP Negeri 7 Padang telah memiliki ketiga bagian struktur teks tersebut. Ketiga struktur akan dijelaskan sebagai berikut.

\section{a. Orientasi}

Secara umum teks cerita fantasi yang ditulis peserta didik kelas VII SMP Negeri 7 Padang sudah memiliki orientasi yang ditulis dalam satu paragraf. Orientasi adalah bagian yang berisi pengungkapan pengenalan tokoh dan latar cerita oleh pengarang. Pengenalan tokoh berkaitan dengan pengenalan pelaku (terutama pelaku utama) meliputi apa saja yang dialami. Pengenalan latar berkaitan dangan waktu, ruang, dan suasana terjadinya peristiwa dalam cerita fantasi. Di dalam teks cerita fantasi yang ditulis peserta didik kelas VII SMP Negeri 7 Padang. Hal tersebut dapat dilihat pada kutipan teks cerita fantasi yang berjudul "Mobile Legends" sebagai berikut.

Pada hari Sening-minggu Saya sedang bermain mobile legend dan Saya Push ranked dengan memakai karakter Roger dan Roger Saya Top Provinsi No. 15 dan Saya wins-streat 10 kali berturut- turut Saat Saya bermain 5 jam Saya merasa ada yang aneh dari Saya. Yaitu saya berubah menjadi Roger dan Situasi Lingkungan Saya mulai berubah. (Data O)

Pada kutipan pertama di atas, terlihatlah bahwa orientasi yang ditulis peserta didik telah mampu menggambarkan dunia fantasi yang ingin dibangunnya. Dunia fantasi yang ingin dibangun peserta didik adalah seorang tokoh yang awalnya sedang bermain mobile legend kemudian masuk ke dalam game tersebut. Peralihan latar tempat dari memainkan mobile legend hingga masuk ke dalam game tersebut menjadikan kutipan ini sebagai bagian orientasi dari cerita fantasi. Orientasi dapat dikelompokkan menjadi dua, yaitu orientasi baik dan orientasi kurang baik. Orientasi yang baik adalah orientasi yang memuat pengenalan tokoh dan latar cerita. Orientasi yang baik ditulis peserta didik kelas VII SMP Negeri 7 Padang dapat dilihat pada kutipan teks cerita fantasi "Dunia Permen" berikut. 
Suatu hari ada seorang anak yang baik dan pintar, namanya ely. Ely adalah anak yang sangat baik dan pintar. Pada malam hari yang sunyi ada sebuah cahaya yang masuk kekamar ely, lalu ely mengikutinya, sampailah ely dititik cahaya itu, dia melihat sosok wanita cantik bagaikan peri, dan ternyata itu memanglah peri yang dikirim oleh tuhan untuk ely.

(Data AK)

Berdasarkan kutipan kedua tersebut, terlihat bahwa orientasi yang ditulis oleh peserta didik kelas VII SMP Negeri 7 Padang sudah baik. Hal itu karena orientasi yang ditulis telah memuat pengenalan tokoh dan latar secara bersamaan. Orientasi pada kutipan tersebut berisikan pengenalan tokoh Ely yang baik dan pintar. Selanjutnya, di dalam kutipan tersebut juga dituliskan latar tempat, suasana, dan pengenalan tokoh lain.

Kutipan yang menyatakan struktur orientasi kurang baik yang terdapat dalam cerita fantasi karya peserta didik kelas VII SMP Negeri 7 Padang dengan judul "Buku Penyelamatan Sihir" sebagai berikut.

Karina dan Zahra adalah sahabat dari kecil mereka selalu bermain berdua di mana ada

Karina di situ pasti ada Zahra. mereka juga sering pergi rekreasi bersama, sehingga mereka sulit untuk dipisahkan. Karina dan Zahra juga memiliki kemiripan sifat, dan sering disebut kembar tapi tak seiras. (Data I)

Berdasarkan kutipan ketiga tersebut, terlihatlah bahwa orientasi yang ditulis peserta didik kelas VII SMP Negeri 7 Padang kurang baik. Hal itu menggambarkan orientasi belum memuat pengenalan tokoh dan latar secara bersamaan. Kutipan tersebut hanya memuat pengenalam tokoh secara analitik. Namun, tidak ditemukan latar tempat, waktu, dan suasana cerita dalam kutipan.

Berdasarkan penjelasan tersebut, dapat disimpulkan bahwa di dalam kutipan teks cerita fantasi peserta didik kelas VII SMP Negeri 7 Padang terdapat bagian orientasi. Orientasi ditandai dengan munculnya pengenalan tokoh dan latar dalam cerita. Struktur orientasi yang ditulis peserta didik sesuai dengan pendapat yang telah dijelaskan oleh Harsiati, Trianto, dan Kosasih (2017) hanya saja masih terdapat kekurangan. Kekurangan yang terjadi adalah ketidaklengkapan pengenalan tokoh dan latar. Peserta didik lebih cenderung mengenalkan tokoh saja. Padahal pada bagian orientasi diperlukan juga pengenalan latar waktu, suasana, dan tempat.

\section{a. Komplikasi}

Teks cerita fantasi yang ditulis peserta didik kelas VII SMP Negeri 7 Padang sudah memiliki komplikasi. Komplikasi muncul diakibatkan oleh adanya konflik. Tahap komplikasi ini ditandai dengan reaksi pelaku dalam cerita fantasi terhadap konflik. Tahap-tahap umum penjalinan konflik dalam cerita fantasi dimulai dari munculnya konflik, peningkatan konflik, hingga konflik memuncak (klimaks). Komplikasi yang ditulis peserta didik dapat dikelompokkan menjadi dua, yaitu komplikasi baik dan komplikasi tidak baik. Komplikasi baik adalah komplikasi yang memuat tahap-tahap umum penjalinan konflik secara keseluruhan. Komplikasi yang baik ditulis peserta didik kelas VII SMP Negeri 7 Padang dapat dilihat pada teks cerita fantasi "Lemari Kaca Ajaib" berikut.

"Tolong Negeri ku, Nisa!" dia menjawabnya. Nisa kaget "ba..bagaimana kamu bisa tau namaku? apa kita pernah bertemu?" tanya nisa. Tanpa menjawab pertanyaan Nisa, laki-laki itu membawa Nisa pergi ke kamar Nisa dan berkata "buka pintu lemari kaca mu ini Nisa.". Nisa pun membukanya, dan alangkah terkejutnya nisa melihat lemari kacanya yang dia buka berubah menjadi dunia negeri lain. "Ti..tidak mungkin!! di mana barang- barangku?! Bajuku, alat tulis yang ku simpan? dimana!! Astaga!!”.

...

Ayahku sedang jatuh sakit, rakyat negeri Bahagia sedang menderita karena tidak ada pakaian, makanan, bahan lainnya. Ini semuanya terjadi karena nenek penyihir itu!" Ujar pangeran Robert yang rupanya adalah laki-laki tersebut. "maaf, kalo boleh tahu siapa penyiar itu?" tanya Nisa. "Siapa lagi kalo bukan penyihir Rosalia! dia mempunyai anak bernama Laposa. Laposa sangat mencintaiku, tapi sayang aku tidak mencintainya. lalu dia dan ibunya 
Rosalia membalas dendam kepada negeriku. Aku... ingin memberitahumu. Bahwa aku dikutuk menjadi kurcaci setelah aku masuk ke duniaku. Tapi jika dunia lain, kutukan itu tidak akan berlaku.

"Nisa tolong aku untuk mengambil kristal warna- warni di daerah negeri sana" tunjuk pangeran. "Baiklah! Ayo" ajak Nisa. Saat Pangeran memijak wilayah daerah penyihir, Pangeran berubah menjadi kurcaci yang buruk rupa. (Data C)

Berdasarkan kutipan keempat tersebut, terlihatlah bahwa komplikasi yang ditulis peserta didik kelas VII SMP Negeri 7 Padang sudah baik. Hal itu terbukti dari adanya perjalinan konflik secara keseluruhan yang terdapat dalam kutipan tersebut. Pertama, munculnya konflik ditandai dengan tokoh Robert yang mengajak Nisa masuk ke Negeri Bahagia melalui pintu lemari Nisa. Kedua, peningkatan konflik ditandai dengan tokoh Robert yang menceritakan bagaimana kondisi yang dialami oleh Negeri Bahagia. Ketiga, puncak konflik (klimaks) ditandai dengan tokoh Nisa dan Robert mengambil kristal dan membawanya ke istana.

Kutipan yang menyatakan struktur komplikasi kurang baik yang terdapat dalam teks cerita fantasi "Tas Adalah Temanku" yang ditulis peserta didik kelas VII SMP Negeri 7 Padang adalah sebagai berikut.

Karena ia merasa bosan sendiri, ia pun berkaca di cermin lemari kamarnya dan berkata "Aku sangat bosan sendiri, aku butuh teman. Andai Aku memiliki teman yang banyak di sekitarku, aku bisa bermain dengan mereka "Famela menangis di depan cermin sambil menutup matanya dengan tangan.

Saat Famela sudah berhenti dan membuka matanya, ada sebuah tas yang ada di sampingnya. "Tas siapa ini?Padahal tadi tas ini tidak ada disini." Tanya Famela. "Aku adalah tas yang akan menemanimu bermain di sini." kata tas itu. "Apa?bagaimana bisa kamu berbicara dan bermain bersama ku, kalau kamu adalah atas? tanya Famela terheranheran. Tiba-tiba tas itu berubah menjadi sosok manusia yang sangat cantik, "Halo namaku Fia, aku akan bermain dan menemanimu. "(Data F)

Berdasarkan kutipan kelima di atas, terlihatlah bahwa komplikasi yang ditulis peserta didik kelas VII SMP Negeri 7 Padang kurang baik. Hal itu dikarenakan komplikasi yang ditulis tidak memuat jalinan konflik secara keseluruhan. Pada kutipan tersebut hanya tahap pemunculan konflik saja, yaitu ketika tokoh dalam cerita menangis karena bosan dan muncul sebuah tas yang dapat berbicara dan berubah wujud menjadi seorang manusia.

Berdasarkan penjelasan tersebut terlihatlah bahwa di dalam struktur teks cerita fantasi peserta didik kelas VII SMP Negeri 7 Padang terdapat bagian komplikasi. Komplikasi ditandai dengan adanya jalinan konflik yang dimulai dari tahap pemunculan konflik, peningkatan konflik, dan terakhir puncak konflik (klimaks). Struktur komplikasi yang ditulis peserta didik sesuai dengan pendapat yang telah dijelaskan oleh Harsiati, Trianto, dan Kosasih (2017) hanya saja masih terdapat beberapa kekurangan. Kekurangan yang terjadi adalah ketidaklengkapan jalinan konflik. Peserta didik hanya sampai pada tahap pemunculan konflik saja dan tidak memberikan penjalinan cerita sampai tahap peningkatan konflik serta puncak konflik (klimaks).

\section{b. Resolusi}

Secara umum teks cerita fantasi yang ditulis peserta didik kelas VII SMP Negeri 7 Padang sudah memiliki resolusi. Resolusi merupakan suatu keadaan ketika konflik terpecahkan dan menemukan penyelesaiannya. Pada tahap ini, pengarang berupaya mengungkapkan solusi dari berbagai konflik yang dialami tokoh utama atau para tokoh cerita. Di dalam teks cerita fantasi yang ditulis peserta didik kelas VII SMP Negeri 7 Padang ditemukan 46 teks cerita fantasi yang memiliki resolusi dan 2 teks yang teks tidak memiliki resolusi. Resolusi yang baik adalah resolusi yang mengungkapkan solusi untuk setiap konflik yang sudah disuguhkan pada bagian komplikasi. Resolusi yang baik ditulis peserta didik kelas VII SMP Negeri 7 Padang dapat dilihat pada kutipan "Lemari Kaca Ajaib" berikut. 
Sesampai di istana, Nisa langsung meletakkan kristalnya di tempatnya tersebut. Sesontak dunia bahagia menjadi lebih cerah dari sebelumnya dan Nisa tiba-tiba ada di tempat tidurnya dalam keadaan sedang tidur. "apa yang terjadi ya? apakah ini mimpi? tanya nisa ke dirinya. lalu dia membuka lemari kacanya. Dan yang dia lihat adalah barang-barangnya seperti semula "mungkin mimpi..." ujar Nisa sambil senyum-senyum sendiri.(Data C)

Berdasarkan kutipan keenam di atas, terlihatlah bahwa resolusi yang ditulis peserta didik kelas VII SMP Negeri 7 Padang telah baik. Hal itu dikarenakan resolusi yang ditulis telah mampu mengungkapkan penyelesaian konflik atau masalah yang disuguhkan pada bagian komplikasi. Berdasarkan analisis data tersebut dapat disimpulkan bahwa struktur teks cerita fantasi karya peserta didik kelas VII SMP Negeri 7 Padang telah sesuai dengan teori yang dikemukakan Harsiati, Trianto, dan Kosasih (2017), yaitu struktur teks cerita fantasi terdiri atas orientasi, komplikasi, dan resolusi. Jadi, dapat disimpulkan secara umum teks cerita fantasi yang ditulis peserta didik kelas VII SMP Negeri 7 Padang sudah sesuai dengan struktur yang ada.

\section{Analisis dari Segi Unsur}

Berdasarkan penelitian yang dilakukan pada teks cerita fantasi yang ditulis peserta didik ditemukan enam unsur teks cerita fantasi, yakni tema, alur, tokoh dan penokohan, latar, sudut pandang, dan amanat.

\section{a. Tema}

Secara umum teks cerita fantasi yang ditulis peserta didik kelas VII SMP Negeri 7 Padang menuliskan tema futuristik, magic, dan supranatural. Tema adalah gagasan utama yang hendak diungkapkan pengarang dalam sebuah karya. Dengan kata lain, tema adalah pokok permasalahan yang menjadi titik penyusunan sebuah cerita. Tema yang sering diangkat dalam sebuah cerita adalah masalah kehidupan. Masalah tersebut berupa pengalaman yang bersifat individual dan sosial. Di dalam teks cerita fantasi yang ditulis peserta didik kelas VII SMP Negeri 7 Padang ditemukan 3 teks cerita fantasi yang bertema futuristik, terdapat 6 teks yang bertema magic, dan 39 teks yang memiliki tema supranatural. Salah satu tema futuristik yang ditulis peserta didik kelas VII SMP Negeri 7 Padang dapat dilihat pada kutipan "Piring Misterius" berikut.

Tiba-tiba Iqbaal keluar dan menarik tangan Rafif untuk masuk. kiranya ia melihat ada piring besar yang antik dan 2 alien kecil seperti anak kelas 3 SD. Iqbaal pun memberanikan diri untuk bertanya. Iqbaal pun berkata " hai, siapa Namamu”. secara spontan salah satu aliran memberikan gelang dan menyuruh Iqbal dan Rafif untuk memakainya. barulah ia berkata " hal, nama Masyuko dan mayumi. kami dari planet Kosmos. salam kenal. Ooo ya, yang kalian pegang itu adalah gelang penerjemah bahasa. (Data J)

Pada kutipan tersebut peserta didik menggambarkan tentang kedatangan piring terbang yang misterius dan juga planet Kosmos. Di dalam cerita juga mencerminkan suatu saat nanti manusia dan makhluk asing akan berteman atau hidup secara berdampingan satu sama lain. Di cerita tersebut juga mengilustrasikan sebuah puding yang dapat mengeluarkan musik.

Selain tema futuristik, peserta didik juga menuliskan tema magic terdapat pada teks "Lemari Kaca Ajaib" dan supernatural pada teks "Negeri Kipas Angin" sebagai berikut.

Ini semuanya terjadi karena nenek penyihir itu!'Ujar pangeran Robert yang rupanya adalah laki-laki tersebut. "maaf, kalo boleh tahu siapa penyihir itu?" tanya Nisa. "Siapa lagi kalo bukan penyihir Rosalia!dia mempunyai anak bernama Laposa. Laposa sangat mencintaiku, tapi sayang aku tidak mencintainya. lalu dia dan ibunya Rosalia membalas dendam kepada negeriku. (Data C)

Pada kutipan di atas terdapat kutipan yang menggunakan tema magic. Hal ini dibuktikan dengan adanya penggunaan penyihir dan mengubah pangeran Robert menjadi kurcaci. Namun, sihir tersebut tidak berlaku jika keluar dari negeri tersebut. Oleh sebab itu, kutipan tersebut membuktikan bahwa teks cerita fantasi ini menggunakan tema magic. 
Sore harinya Prilly datang ke rumah Putri. Mereka bermain di dalam kamar Putri, karena merasa gerah Putri menghidupkan kipas angin hadiah dari Balkan tadi, kipas angin sangat kencang sehingga membuat mereka terhisap ke dalam kipas angin. Tiba-tiba mereka sampai di sebuah negeri, mereka terkejut karena orang-orang dan rumah yang di sana sangat berbeda.

(Data B)

Pada kutipan di atas terdapat kutipan yang menggunakan tema supranatural. Hal ini dibuktikan dengan kipas angin yang bisa menghisap mereka masuk ke dalam kipas angin dan sampai di sebuah negeri yang hampir keseluruhannya mirip dengan kipas angin. Oleh sebab itu, kutipan tersebut membuktikan bahwa teks cerita fantasi ini menggunakan tema supranatural.

Berdasarkan penjelasan tersebut, dapat disimpulkan bahwa di dalam kutipan teks cerita fantasi peserta didik kelas VII SMP Negeri 7 Padang terdapat bagian tema. Tema terbagi atas tiga bagian, (1) futuristic, (2) magic, dan (3) supranatural. Berdasarkan yang telah dijelaskan oleh Harsiati, Trianto, dan Kosasih tema merupakan pokok permasalahan yang menjadi titik penyusunan sebuah cerita. Pokok pikiran yang disampaikan oleh peserta didik sudah sangat bagus. Tiga bagian dari tema, peserta didik lebih cenderung menulis teks cerita fantasi yang bertemakan supranatural dibandingkan dengan magic dan futuristik. Kecendrungan yang terjadi lebih signifikan, hal ini bisa disebabkan dari pola pikir peserta didik yang masih beranggapan kalau teks cerita fantasi adalah teks yang berhubungan dengan supranatural.

\section{b. Alur}

Alur atau plot adalah jalan cerita yang mempunyai hubungan kronologis dan sebabakibat. Alur terbagi atas tiga, yaitu alur konvensional, alur nonkonvensional, dan alur campuran. Pertama, alur konvensional atau alur progresif (maju), yaitu peristiwa dalam cerita dinarasikan secara kronologis atau urut dari awal sampai akhir. Kedua, alur nonkonvensional atau sorot balik (mundur), yaitu peristiwa dalam cerita dinarasikan dengan menoleh ke belakang atau membayangkan masa lalu. Ketiga, alur campuran atau maju mundur, yaitu peristiwa dalam cerita meloncat- loncat antara masa lalu dan masa kini seperti contoh teks "Lemari Kaca Ajaib" berikut.

"Tolong Negeri ku, Nisa!" dia menjawabnya. Nisa kaget "ba..bagaimana kamu bisa tau namaku? apa kita pernah bertemu?" tanya nisa. Tanpa menjawab pertanyaan Nisa, laki-laki itu membawa Nisa pergi ke kamar Nisa dan berkata "buka pintu lemari kaca mu ini Nisa.". Nisa pun membukanya, dan alangkah terkejutnya nisa melihat lemari kacanya yang dia buka berubah menjadi dunia negeri lain. "Ti..tidak mungkin!! di mana barang- barangku?! Bajuku, alat tulis yang ku simpan? dimana!! Astaga!!”.

Ayahku sedang jatuh sakit, rakyat negeri Bahagia sedang menderita karena tidak ada pakaian, makanan, bahan lainnya. Ini semuanya terjadi karena nenek penyihir itu!" Ujar pangeran Robert yang rupanya adalah laki-laki tersebut. "maaf, kalo boleh tahu siapa penyiar itu?" tanya Nisa. "Siapa lagi kalo bukan penyihir Rosalia! dia mempunyai anak bernama Laposa. Laposa sangat mencintaiku, tapi sayang aku tidak mencintainya. lalu dia dan ibunya Rosalia membalas dendam kepada negeriku. Aku... ingin memberitahumu. Bahwa aku dikutuk menjadi kurcaci setelah aku masuk ke duniaku. Tapi jika dunia lain, kutukan itu tidak akan berlaku.

$\cdots$

"Nisa tolong aku untuk mengambil kristal warna- warni di daerah negeri sana" tunjuk pangeran. "Baiklah! Ayo" ajak Nisa. Saat Pangeran memijak wilayah daerah penyihir, Pangeran berubah menjadi kurcaci yang buruk rupa. (Data C)

Pada kutipan tersebut menggambarkan alur cerita dari awal sampai akhir dengan runtun. Alurnya terus maju, tidak ada mengambil kisah yang telah berlalu atau kisah yang lompat dari masa ke masa. Berdasarkan penjelasan tersebut, dapat disimpulkan bahwa di dalam kutipan teks cerita fantasi peserta didik kelas VII SMP Negeri 7 Padang terdapat bagian alur.

JESS, Open Access Journal: http://jess.ppj.unp.ac.id/index.php/JESS 
Penjelasan alur berdasarkan pendapat Harsiati, Trianto, dan Kosasih (2017) itu sendiri adalah jalan cerita yang mempunyai hubungan sebab-akibat. Secara umum tulisan peserta didik terseebut sudah menjelaskan sebab akibat dalam peristiwa yang terjadi. Ada yang tampak secara rapi dijelaskan dan ada yang masih sedikit sulit dipahami. Berdasarkan hasil analisis penulis, seluruh peserta didik cenderung menulis teks cerita fantasi secara maju. Tidak ada satupun peserta didik yang menulis teks cerita fantasi beralur mundur atau campuran. Hal ini membuktikan kalau peserta didik masih minim penggunaan alur mundur dan campuran.

\section{c. Tokoh dan Penokohan}

Tokoh adalah pelaku dalam sebuah cerita. Tiap-tiap tokoh memiliki watak, sifat, dan kondisi fisik yang disebut dengan perwatakan/penokohan. Dilihat dari watak yang dimiliki, tokoh dapat dibedakan atas tokoh protagonis dan tokoh antagonis. Tokoh protagonis adalah tokoh yang wataknya baik dan positif, seperti dermawan, jujur, rendah hati, pembela, cerdik, pandai, mandiri, dan setia kawan. Sebaliknya, tokoh antagonis adalah tokoh yang wataknya biasa digambarkan sebagai tokoh yang berwatak buruk dan negatif, seperti pendendam, pembohong, culas, sombong, iri, dan suka pamer. Hal ini bisa dilihat pada teks "Botol Ajaib" berikut.

Tiara menyapanya "Hei siapa nama kamu?" "Nama aku Tito," kata anak tersebut. Tiara pun memanggil Ruby, "Ruby aku tidak pernah melihat anak ini di dalam kompleks kita," "Sama aku juga tidak pernah melihatnya" kata Ruby.Lalu Tito dibawa ke rumah Tiara dan Ruby pulang ke rumahnya untuk mengganti pakaian dan baru ke rumah Tiara. (Data D)

Pada kutipan tersebut menggambarkan tokoh protagonist, yaitu Tiara dan Ruby yang ramah terhadap orang yang baru ditemuinya. Hal itu dibuktikan dengan Tiara dan Ruby yang ramah menyapa saat mereka menemukan Tito dan membawanya ke rumah Tiara. Hal ini bisa dilihat pada teks "Lemari Kaca Ajaib" berikut.

Laposa sangat mencintaiku, tapi sayang aku tidak mencintainya. lalu dia dan ibunya Rosalia membalas dendam kepada negeriku. Aku... ingin memberitahumu. Bahwa aku dikutuk menjadi kurcaci setelah aku masuk ke duniaku. Tapi jika dunia lain, kutukan itu tidak akan berlaku. (Data C)

Pada kutipan tersebut menggambarkan tokoh antagonis dari penyihir Rosalia. Rosalia mengutuk pengeran Robert menjadi kurcaci karena anaknya Laposa sangat mencintai pengeran Robert. Namun, pangeran menolaknya. Hal itu membuktikan kalau tokoh penyihir Rosalia adalah penyihir yang pendendam.

Penokohan adalah penggambaran jelas tentang seorang tokoh dalam cerita. Penggambaran tersebut akan tercermin pada pikiran, ucapan, dan pandangan tokoh terhadap sesuatu. Ada dua metode yang digunakan untuk menggambarkan penokohan, yaitu metode analitik dan metode dramatik. Metode analitik adalah metode penokohan yang memaparkan atau menyebutkan sifat tokoh secara langsung. Kemudian, metode dramatik adalah metode penokohan yang tidak langsung memaparkan atau menggambarkan sifat tokoh. Penokohan dilakukan melalui penggambaran fisik, penggambaran melalui percakapan yang dilakukan tokoh lain, dan teknik reaksi tokoh lain yang berupa pandangan, pendapat, sikap, dan komentar. Hal ini bisa dilihat dari kutipan teks "Piring Misterius" berikut.

Ada seorang anak yang bernama Rafif, Iya itu adalah anak yang sangat aktif. baik dirumah maupun disekolah. Ia memiliki 1 teman yang selalu membelanya. namanya Iqbal. Iqbal ini adalah anak yang sangat pintar. apabila di sekolah ia selalu ranking satu. Ia tidak mudah percaya orang lain. Ia hanya percaya kalau ada buktinya terlebih dahulu. (Data J)

Pada kutipan tersebut menggambarkan tokoh secara analitik. Hal itu dibuktikan dengan penulis menggambarkan sosok Rafif sebagai anak yang aktif baik di sekolah maupun di rumah. Kemudian sosok Iqbal yang digambarkan sosok tokoh yang sangat pintar, selalu ranking satu, dan tipikal orang yang tidak mudah percaya sebelum ada buktinya. Karakter tokoh tersebut digambarkan secara jelas oleh penulis dalam teks "Dunia Dibalik Lemari" berikut. 
Setelah mereka selesai belajar teman-teman Rindu menuju kamar Rindu. Mereka melihatlihat kamarnya. Salah satu temannya Rindu yang bernama Kejora, mendekati lemari belajar Rindu. Tiba-tiba rindu berteriak "Rindu kesini cepat!!" lalu rindu dan teman-temannya bergegas menuju lemari belajar rindu. "Kenapa Kejora?" mereka berkata. "Liat ini!Kejora berseru.Rindu tombol apakah ini?Dengan penasaran Rindu menekan tombol yang asing itu baginya. Dan seketika! Aaa..., mereka terlempar kedunia lain. (Data Q)

Pada kutipan tersebut menggambarkan tokoh secara dramatik. Hal itu dibuktikan dengan penulisa menggambarkan sosok Kejora yang sangat penasaran dengan tombol merah ketika dia mendekati lemari belajar yang ada di dalam kamar Rindu. Karena penasaran dia sampai memanggil Rindu untuk memastikan tombol merah tersebut dengan memencetnya. Sehingga mereka terlempar ke dunia lain setelah menekan tombol tersebut.

Berdasarkan penjelasan tersebut, dapat disimpulkan bahwa di dalam kutipan teks cerita fantasi peserta didik kelas VII SMP Negeri 7 Padang terdapat bagian tokoh dan penokohan. Harsiati, dkk. menjelaskan tokoh sebagai pelaku yang diceritakan dalam suatu peristiwa. Setiap pelaku tersebut memiliki watak atau biasa disebut penokohan. Watak yang diceritakan cenderung memiliki sifat protagonis dibandingkan dengan sifat antagonis. Bahkan ada beberapa dari cerita tersebut tidak menampilkan tokoh antagonis melainkan tokoh protagonis saja yang berupaya menyelesaikan masalahnya sendiri dengan keajaiban-keajaiban yang tidak diduga.

\section{d. Latar}

Latar atau setting merupakan kesatuan tempat, waktu, dan suasana yang menjadi wadah tokoh untuk terlibat dalam peristiwa yang diungkapkan dalam cerita. Latar juga merupakan tempat dan urutan waktu ketika suatu tindakan berlangsung. Tindakan atau peristiwa selalu berada dalam keterkaitannya antara waktu dan tempat. Unsur latar ini meliputi latar tempat, waktu, dan suasana. Perhatikan kutipan dalam teks "Negeri Kipas Angin" berikut.

Pagi hari Putri dan Prilly sedang bermain di taman yang ada di belakang rumah mereka, di sana mereka bisa bermain ayunan, dan lain-lain, saat mereka asyik bermain, mereka melihat seorang peri yang terjatuh "aduh!" kata peri sambil kesakitan, Putri dan Prilly segera menghampiri dan menolong peri "apakah kau baik-baik saja?” tanya Putri. (Data B)

Pada kutipan tersebut digambarkan latar yang lengkap oleh penulis. Latar waktu yang terjadi pada pagi hari. Latar tempat yang diceritakan berada di taman yang ada di belakang rumah mereka. Suasana yang digambarkan dalam keadaan senang karena mereka asyik bermain di taman tersebut. Penggambaran latar pada cerita ini diceritakan secara gamblang oleh penulis.

Berdasarkan hasil analisi dari penjelasan tersebut, dapat disimpulkan bahwa di dalam kutipan teks cerita fantasi peserta didik kelas VII SMP Negeri 7 Padang terdapat latar dalam teks cerita fantasi. Harsiati, Trianto, dan Kosasih (2017) menuturkan latar sebagai kesatuan tempat, waktu, dan suasana yang menjadi wadah tokoh yang terlibat dalam peristiwa yang diungkapkan dalam cerita. Latar tempat yang diceritakan dominan terjadi di kamar, taman, dan juga sebuah istana. Penceritaan latar tempat masih terfokus kepada contoh yang pernah diberikan. Pada contoh tersebut latar tempat yang diceritakan, yaitu kamar, taman, dan juga sebuah istana. Untuk latar suasana, peserta didik lebih cenderung membuat suasana yang bahagia melihat suatu keajaiban yang terjadi kemudian sedih karena kembali kejadian semula disebabkan melanggar larangan yang telah ditetapkan. Ada juga beberapa latar suasana bahagia karena telah menyelesaikan misi yang diberikan. Berdasarkan hal itu, secara keseluruhan latar dalam tulisan peserta didik tersebut tidak jauh berbeda dari contoh yang pernah diberikan.

\section{e. Sudut Pandang}

Sudut pandang atau point of view merupakan cara pandang yang digunakan pengarang sebagai sarana untuk menyajikan tokoh, tindakan, latar, dan berbagai peristiwa yang membentuk cerita. Pada teks cerita fantasi yang ditulis oleh peserta didik kelas VII SMP 
Negeri 7 Padang semuanya mengambil sudut pandang orang ketiga. Hal ini dibuktikan dalam kutipan teks "Lemari Kaca Ajaib" tersebut.

Di suatu pagi, Nisa sedang bermain dengan kucing kesayangannya, si pupus. Mereka berlarian kesana ke sini sambil bermain. Tiba-tiba, muncul seorang manusia laki-laki di depan Nisa. (Data C)

Pada kutipan tersebut menggambarkan penulis sebagai narator dalam teks cerita fantasi karya peserta didik kelas VII SMP Negeri 7 Padang. Hal itu dibuktikan dengan penyebutan nama tokoh, kata ganti -nya, dia, mereka yang warnanya ditebalkan. Bedasarkan hasil analisis peneliti dari segi sudut pandang, peneliti menemukan kecenderungan peserta didik menulis teks cerita fantasi menggunakan sudut pandang orang ketiga. Hanya satu karya peserta didik yang menulis sudut pandang orang pertama. Seperti yang sudah dijelaskan oleh Harsiati, Trianto, dan Kosasih (2017) bahwa sudut pandang itu merupakan cara pandang narator dalam menyampaikan tokoh, alur, serta peristiwa yang akan diceritakan. Sudut pandang orang ketiga ini narator akan menyebutkan tokoh dalam cerita tersebut dengan kata dia, mereka, nama, dan - nya.

\section{f. Amanat}

Amanat adalah pesan yang ingin disampaikan dalam sebuah cerita. Pesan dalam sebuah cerita mencerminkan pandangan hidup pengarang. Pesan yang ingin disampaikan pengarang disebut pesan moral. Pesan moral tersebut dapat berupa penerapan sikap dan tingkah laku para tokoh yang terdapat pada sebuah cerita.

Esten (dalam Prayogo, 2012) menyatakan bahwa amanat dalam sebuah cerita biasanya dapat diketahui secara eksplisit, yakni amanat itu berupa suatu ajaran atau petunjuk yang ditujukan langsung kepada pembaca, sedangkan dengan implisit karena jalan keluar diisyaratkan di dalam tingkah laku tokoh menjelang berakhirnya cerita. Berikut kutipan teks cerita fantasi karya peserta didik kelas VII SMP Negeri 7 Padang secara implisit dan eksplisit. Secara implisit terdapat dalam teks "Botol Penyelamat Tumbuhan":

Sorenya, sang ratu Evelyn memberi 3 sahabat itu penghargaan berupa piagam, tropi, dan medali. Itu diberikan di depan semua warga negeri tumbuhan. Semuanya bertepuk tangan dengan meriah. Keajaiban kali ini membuat mereka sadar bahwasannya kita harus perduli terhadap lingkungan. Petualangan pun berakhir di sini. (Data A)

Pada kutipan tersebut, disebutkan secara jelas apa pesan moral yang ingin disampaikan oleh penulis kepada pembaca, yaitu kita harus peduli terhadap lingkungan disekitar kita. Jangan sampai sampah mengotori lingkungan dan tetap menjaga ekosistem tumbuhan untuk terus memberikan manfaatnya. Sedangkan secara eksplisit:

Datanglah seorang wanita ke tempat Tata, dia bernama Liza. Dia adalah seorang yang membantuTata untuk mengetahui tempat- tempat di masa tersebut. Lisa juga mengatakan kepada Tata "walaupun kamu terkagum-kagum melihat dunia ini, kamu jangan pernah mengatakan wow".

Mereka mengelilingi tempat-tempat tersebut. Setibanya di tempat yang sangat indah, kata terkagum dan melupakan apa yang Lisa bilang Papa mengatakan "wow "dan tempat yang indah itu hancur. Tata pun kembali ke masa sekarang. kata bahagia karena telah bisa ke masa depan. dia juga menyesal karena tidak patuh pada aturan Lisa.

Pada kutipan tersebut, tidak disebutkan secara jelas apa pesan moral yang ingin disampaikan oleh penulis kepada pembaca. Pada kutipan tersebut pesan moral yang ingin disampaikan oleh penulis, yaitu patuhi aturan atau larangan yang ada disekitar tempat kita tinggal, di tempat orang, dan sebagainya. Hal itu menjadi peringatan untuk kita selalu berhati-hati karena kita tidak akan tahu apa akibat yang akan terjadi jika kita melanggar aturan yang ada. Pesan itu juga menyampaikan bahwa kita harus bersikap hati-hati dan jangan terlalu berlebihan dalam memperlihatkan atau mengekspresikan sesuatu secara berlebihan. 
Pesan atau amanat yang terkandung dalam teks cerita fantasi yang ditulis peserta didik lebih cenderung menyampaikan pesan secara eksplisit. Kecenderungan ini juga diakibatkan dari contoh atau model teks cerita fantasi yang diajarkan. Pembagian eksplisit dan implisit ini didasarkan pada pendapat Esten. Esten (dalam Prayogo, 2012) membagi penyampaian amanat atau pesan dalam teks cerita fantasi secara eksplisit dan implisit atau orang awam mengenal secara tersurat dan tersirat. Tulisan peserta didik cenderung menggunkan secara eksplisit dikarenakan mereka masih meniru model yang diberikan.

\section{Berdasarkan Tipe}

Tipe teks cerita fantasi berdasarkan kesesuaiannya dengan dunia nyata dan berdasarkan latar cerita. Pertama, berdasarkan kehidupan nyata ada dua kategori. Kedua, berdasarkan latar cerita, cerita fantasi dibedakan mejadi dua kategori yaitu latar lintas waktu dan latar waktu sezaman. Pada teks cerita fantasi yang ditulis peserta didik ditemukan dua tipe teks cerita fantasi, yaitu berdasarkan kesesuaian dengan kehidupan nyata dan berdasarkan latar cerita.

\section{a. Berdasarkan Kesesuaian dengan Kehidupan Nyata}

\section{1) Fantasi Total}

Kategori cerita fantasi total berisi fantasi pengarang terhadap objek tertentu. Pada cerita kategori fantasi total semua yang terdapat pada cerita tidak terjadi di dunia nyata. Hal ini bisa dilihat dalam teks "Alexa dan Buku Ajaibnya" berikut.

Alexa Seorang putri mehkota yang cantik dan selalu baik kepada semua orang. Ia Senang sekali membaca buku sehingga Alexa mempunyai perpustakannya sendiri. Raja ingin Sekali anak Semata wayangnya itu menjadi pewaris tahta dan menjaga kerajaan ini ketika ia sudah mati nanti. Sebenarnya, Alexa tidak ingin menjadi pewaris tahta karna ia lebih suka berdiam diri dikmarnya Sambil membaca buku.

$$
\cdots
$$

Ia baru saja menginjakkan kakinya ditempat itu pakaiannya berubah seketika dan dengan adanya tongkat ajaib yang misterius. Saat sedang berjalan ia melihat seorang gadis yang sedang menangis terisak- isak. "Kenapa kamu menangis, apakah aku bisa membantumu," tanya Alexa keapda gadis itu. ia menceritakan semua permasalahan yang ia alamai dan ternyata nama gasid itu ialah Ana. (Data AM)

Pada kutipan tersebut, menceritakan seorang putri mahkota yang bernama Alexa yang tidak ingin mewarisi tahta kerajaan. Kemudian dia diberi sebuah buku yang di dalamnya terdapat tombol merah dalam selembar kertas. Kalau dibawakan ke dunia nyata tidak ada tombol merah atau tombol apapun yang akan membawa kita ke suatu negeri yang ajaib dan misterius.

\section{2) Fantasi Irisan}

Cerita fantasi irisan yaitu cerita fantasi yang mengungkapkan nama-nama dalam kehidupan nyata, tempat yang ada dalam dunia nyata, atau peristiwa yang pernah terjadi di dunia nyata. Hal ini bisa dilihat dalam teks "Tumblr yang Ajaib" berikut.

Ada seorang anak yang bernama Cinta. Pada suatu hari Jum'at, Cinta ingin mempersiapkan diri untuk pergi kekampung pada hari Sabtu-Minggu.Cinta ingin memakai sepatu barunya yang ada di bawah kasur, disebalah kotak sepatu barunya ada tumblr kono yang berwarna biru.Karena penasaran, cinta membuka tumblr itu. Dan keluarlah jin yang bernama Tono, Cinta pun ketakutan melihat Tono. "gausah takut, saya adalah jin yang baik" kata Tono. (Data AP)

Pada kutipan teks cerita fantasi karya peserta didik SMP Negeri 7 Padang menggambarkan sebuah teks cerita fantasi irisan. Hal ini dibuktikan bahwa tumblr ada pada kehidupan nyata. Tumblr merupakan salah satu jenis botol air minum yang terkenal pada saat ini. Kemudian di dalam tumblr terdapat seorang jin yang bisa mengabulkan permintaan tuannya yang telah membebaskannya dari tumbrl tersebut. 
Berdasarkan analisis teks cerita fantasi total dan irisan, peserta didik lebih cenderung atau dominan menulis teks cerita fantasi secara irisan. Peserta didik lebih sering mendapatkan contoh atau model dengan teks cerita fantasi irisan. Sifat peserta didik yang masih condong meniru membuat peserta didik sedikit sulit melakukan pengembangan dengan metode yang ada. Secara keseluruhan peserta didik menulis teks cerita fantasi secara irisan. Namun, ditemukan satu karya yang menulis teks cerita fantasi secara total. Teks cerita fantasi total yang ditulis sangat bagus, peserta didik mampu menghadirkan cerita fantasi dengan tokoh dan peristiwa yang belum pernah terjadi di dunia nyata.

\section{Berdasarkan Latar Cerita}

1) Sezaman

\section{a) Masa Lampau}

Berdasarkan latar cerita sezaman kategori masa lampau, penulis mengungkapkan namanama, tempat, atau peristiwa yang pernah terjadi di masa lalu seperti dalam teks "Tas Adalah Temanku".

Karena ia merasa bosan sendiri, ia pun berkaca di cermin lemari kamarnya dan berkata "Aku sangat bosan sendiri, aku butuh teman. Andai Aku memiliki teman yang banyak di sekitarku, aku bisa bermain dengan mereka "Famela menangis di depan cermin sambil menutup matanya dengan tangan.

Saat Famela sudah berhenti dan membuka matanya, ada sebuah tas yang ada di sampingnya. "Tas siapa ini? Padahal tadi tas ini tidak ada disini." Tanya Famela. "Aku adalah tas yang akan menemanimu bermain di sini." kata tas itu. "Apa?bagaimana bisa kamu berbicara dan bermain bersama ku, kalau kamu adalah atas? tanya Famela terheranheran.

Tiba-tiba tas itu berubah menjadi sosok manusia yang sangat cantik, "Halo namaku Fia, aku akan bermain dan menemanimu." keta tas tadi yang sekarang berubah menjadi manusia bernama Fia. (Data F)

Pada kutipan teks cerita fantasi karya peserta didik SMP Negeri 7 Padang menggambarkan sebuah teks cerita fantasi sezaman dengan cerita masa lampau. Hal ini dibuktikan bahwa Famela mendapatkan seorang teman dari sebuah tas yang berubah menjadi Fia. Peristiwa itu terjadi dalam waktu yang sama atau tidak lompatan waktu di dalam kisah tersebut. Kemudian kisah jin botol sudah kita kenal sejak zaman-zaman dahulu, seperti jin dan lampu ajaib.

\section{b) Masa Kini}

Berdasarkan latar cerita sezaman kategori masa kini, penulis mengungkapkan namanama, tempat, atau peristiwa yang sedang terjadi di masa kini atau saat sekarang yang tergambar dalam teks "Mobile Legends".

Pada hari Sening-minggu Saya sedang bermain mobile legend dan Saya Push ranked dengan memakai karakter Roger dan Roger Saya Top Provinsi NO. 15 dan Saya winsstreat 10 kali berturut- turut Saat Saya bermain 5 jam Saya merasa ada yang aneh dari Saya. (Data O)

Pada kutipan teks cerita fantasi karya peserta didik SMP Negeri 7 Padang menggambarkan sebuah teks cerita fantasi sezaman dengan gambaran masa kini. Hal ini dibuktikan dengan game mobile legend. Saat ini game tersebut sangat popular dikalangan anakanak saat ini. Salah satu yang menjadikan cerita fantasi ini sebagai cerita fantasi adalah tokoh saya yang sedang bermain mobile legend masuk ke dalam permainan tersebut.

\section{c) Futuristik}

Berdasarkan latar cerita sezaman kategori futuristik, penulis mengungkapkan nama-nama, tempat, atau peristiwa yang akan terjadi di masa yang akan datang atau sebuah khayalan 
yang akan diwujudkan di tahun atau masa depan yang tergambar dalam teks "Piring Misterius".

Tiba-tiba Iqbaal keluar dan menarik tangan Rafif untuk masuk. kiranya ia melihat ada piring besar yang antik dan 2 alien kecil seperti anak kelas 3 SD. Iqbaal pun memberanikan diri untuk bertanya. Iqbaal pun berkata " hai, siapa Namamu". secara spontan salah satu aliran memberikan gelang dan menyuruh Iqbal dan Rafif untuk memakainya. barulah ia berkata " hal, nama Masyuko dan mayumi. kami dari planet Kosmos. salam kenal. Ooo ya, yang kalian pegang itu adalah gelang penerjemah bahasa. dengan itu kalian dapat mengetahui apa yang kami ucapkan". " wow, kalian Mirip ya. ya Yang mana Masyiumi dan mana Masyiumi" Rafif pun memberanikan diri untuk bertanya. (Data J)

Pada kutipan teks cerita fantasi karya peserta didik SMP Negeri 7 Padang menggambarkan sebuah teks cerita fantasi sezaman dengan gambaran futuristik. Hal ini dibuktikan dengan berinteraksinya manusia dengan alien. Suatu makhluk yang sampai saat ini masih belum jelas keberadaanya. Kemudian juga terdapat keanehan seperti puding yang bisa mengeluarkan musik ketika disebutkan kata "beraksi". Kejadian tersebut hanya terjadi pada satu tempat saja dan hanya di zaman yang sama.

\section{2) Lintas Waktu}

Latar lintas waktu berarti cerita fantasi menggunakan dua latar waktu yang berbeda (misalnya, masa kini dengan zaman prasejarah, masa kini dan masa yang akan datang/futursitik).

\section{a) Masa Kini dan Masa Lampau}

Berdasarkan latar lintas waktu masa kini dan masa lampau, penulis mengungkapkan nama-nama, tempat, atau peristiwa yang akan terjadi di masa kini dan juga masa lampau. Berikut contoh dalam teks "Lemari Kaca Ajaib".

Di suatu pagi, Nisa sedang bermain dengan kucing kesayangannya, si pupus. Mereka berlarian kesana ke sini sambil bermain. Tiba- tiba, muncul seorang manusia laki-laki di depan Nisa. Dia sangat tampan... pikir Nisa dalam hatinya. Namun, yang dilihat nisa, raut muka wajah laki-laki itu tampak sedih dan Nisa pun bertanya "ada apa?" sesontak Nisa langsung lupa dengan keheranannya dengan laki-laki yang secara tiba-tiba datang di depannya. "Tolong Negeriku, Nisa!" dia menjawabnya. Nisa kaget "ba..bagaimana kamu bisa tau namaku? apa kita pernah bertemu?" tanya nisa. Tanpa menjawab pertanyaan Nisa, laki-laki itu membawa Nisa pergi ke kamar Nisa dan berkata "buka pintu lemari kaca mu ini Nisa.". Nisa pun membukanya, dan alangkah terkejutnya nisa melihat lemari kacanya yang dia buka berubah menjadi dunia negeri lain."Ti..tidak mungkin!! di mana barangbarangku?!Bajuku, alat tulis yang ku simpan? dimana!! Astaga!!”. Ujar Nisa. "Tenang nisa, barang-barangmu ada, dan disimpan di tempat lain. (Data C)

Pada kutipan teks cerita fantasi karya peserta didik SMP Negeri 7 Padang menggambarkan sebuah teks cerita fantasi lintas zaman dengan gambaran masa kini dengan masa lampau. Hal ini dibuktikan dengan Nisa yang sedang asyik bermain dengan kucingnya tiba-tiba ada orang datang yang mengajaknya untuk pergi ke negeri bahagia yang bisa dikatan negeri yang hanya ada di dongeng- dongeng pada zaman dahulu.

\section{b) Masa Kini dan Futuristik}

Berdasarkan latar cerita lintas waktu masa kini dan masa depan atau futuristik, penulis mengungkapkan nama-nama, tempat, atau peristiwa yang akan terjadi di masa yang akan datang atau sebuah khayalan yang akan diwujudkan di tahun atau masa depan seperti yang tergambar dalam teks "Berpetualang ke Masa Depan".

Pada saat itu ada sehelai kertas terbang dan mereka membacanya. Kertas itu berisi pesan bahwa mereka harus melawan warga dari bahaya. Tiba-tiba mereka masuk ke negeri yang tidak mereka ketahui, setelah lama berjalan mereka bertemu seorang perempuan. Mereka pun bertanya "Dimanakah ini?" tanya Ana. "Ini dimasa depan," Jawab perempuan tersebut, 
"Perkenalkan nama saya Jeni", kata perempuan tersebut. Setelah berbincang Ana pun diajak jalan- jalan, diperjalanan mereka bingung dengan mobil yang bisa terbang dan rumah yang bisa melayang serta robot disetiap restoran. Setelah itu Jeni menceritakan semua keanehan yang ada di negerinya. (Data V)

Pada kutipan teks cerita fantasi karya peserta didik SMP Negeri 7 Padang menggambarkan sebuah teks cerita fantasi lintas zaman dengan gambaran masa kini dengan masa yang akan datang. Hal ini dibuktikan dengan tokoh Ana yang masuk ke suatu negeri yang tidak tahu negeri apa. Di negeri tersebut terdapat mobil yang bisa terbang, rumah yang bisa melayang, serta robot yang ada di setiap restaurant. Kecanggihan itu saat ini menjadi rancangan masa depan di dunia nyata.

Berdasarkan analisis teks yang ditulis peserta didik. Mereka telah menggunakan tipe teks cerita fantasi pada tulisannya. Berdasarkan teori yang dikemukakan oleh Asih (2019), tipe dalam teks cerita fantasi terbagi atas dua. Dua tipe tersebut, berdasarkan kesesuaian dengan dunia nyata dan berdasarkan latar belakang. Berdasarkan dengan kesesuaian dunia nyata, peserta didik lebih cenderung menulis teks cerita fantasi irisan dibandingkan dengan teks cerita fantasi total. Kemudian berdasarkan latar cerita, peserta didik lebih cenderung menuliskan teks cerita fantasi berlatarkan masa kini dan masa lampau. Hal ini membuktikan bahwa kecenderungan peserta didik ini menggambarkan bahwa peserta didik masih kurang menggunakan variasi dari tipe teks cerita fantasi yang ada.

\section{Simpulan}

Berdasarkan hasil penelitian, dapat disimpulkan tiga hal. Pertama, dalam penelitian struktur, peserta didik sudah memenuhi ketiga struktur teks cerita fantasi tersebut, yaitu orientasi, komplikasi, dan resolusi. Hal itu terbukti dari 48 teks cerita fantasi yang dianalisis, terdapat 46 teks cerita fantasi memiliki struktur yang lengkap dan kecenderungan peserta didik membuat orientasi dengan satu paragraf. Kedua, jika dilihat dari unsur ditemukan kecenderungan dalam penulisan sebagai berikut. Tema yang digunakan cenderung kepada tema supranatural. Secara keseluruhan teks siswa membuat alur maju. Toko dan penokohan yang digambarkan cenderung protagonist dibandingkan dengan antagonis dan penggambaran watak dari tokoh dominan secara dramatik. Latar yang digunakan secara keseluruhan masih meniru dari model yang diberikan ketika memberikan pemeblajaran teks cerita fantasi. Sudut pandang yang digunakan sudut pandang orang ketiga hanya ada satu teks yang menggunkan sudut pandang orang pertama. Kemudian amanat yang digunakan cenderung secara eksplisit. Ketiga, pada tipe teks cerita fantasi terbagi dua, yaitu (1) berdasarkan kesesuaian dengan dunia nyata, peserta didik lebih cenderung menulis cerita fantasi irisan dan (2) berdasarkan latar cerita, peserta didik cenderung menuliskan cerita secara lintas waktu yaitu dari masa kini ke masa lampau.

\section{Daftar Kepustakaan}

Arikunto, S., Suhardjono, \& Supardi. (2015). Penelitian Tindakan Kelas - Google Books: Vol. Cetakan Pertama. Jakarta: PT Bumi Aksara.

Asih, L. M. (2019). Campur Kode Pada Karangan Fantasi Peserta didik Kelas Vii Smpn 24 Kota Tangerang. Skirpsi. Jakarta: UIN Syarif Hidayatullah.

Hartendi, Bayu. (2019). Struktur dan Kebahasaan Teks Cerita Fantasi Karya Peserta didik Kelas VII SMP Negeri 5 Rambah Hilir, Kabupaten Rokan Hulu, Provinsi Riau. Skripsi. Padang: FBS UNP.

Fajria, N. (2017). Pelaksanaan Pembelajaran Teks Cerita Fantasi di Kelas VII F SMP Negeri 8 Yogyakarta. Skipsi. Yogyakarta: Program Studi Pendidikan Bahasa Dan Sastra Indonesia Fakultas Bahasa dan Seni Universitas Negeri Yogyakarta.

Fandini, Intan. (2018). Penguasaan Struktur Teks dan Unsur Kebahasaan Cerita Fantasi Peserta didik Kelas VII A SMP Negeri 3 Wonomulyo Kabupaten Polewali Mandar. Skripsi. Sulawesi: Universias Negeri Makasar. 
Gunawan, L. R. (2016). Tanggapan Guru Bahasa Indonesia Terhadap Problem Pembelajaran Sastra Dan Upaya Mengatasinya di SMP Kabupaten Sukoharjo. Skripsi. Pendidikan Bahasa Indonesia Fakultas Keguruan Dan Ilmu Pendidika Universitas Muhammadiyah Surakarta.

Harsiati, T., Trianto, A., \& Kosasih, E. (2017). Buku Peserta Didik Bahasa Indonesia: Vol. Cetakan Ke-4.

Jumesa, E. N., Abdurahman, \& Emidar. (2018). Tokoh Dan Penokohan Dalam Teks Cerita Fantasi Karya Peserta didik Kelas VII Smp Negeri 1 Payakumbuh. Jurnal Pendidikan Bahasa Dan Sastra Indonesia, Vol. 1 No. 7, 112-116.

Kemendikbud. (2013). Peraturan Pemerintah No. 64 Tahun 2013 Tentang Standar Isi. Jakarta: Kementrian Pendidikan dan Kebudayaan Republik Indonesia.

Mustika, Delfitria, Nursaid, dan Ena Noveria. (2018). "Struktur, Diksi, dan Kalimat dalam Teks Cerita Fantasi Karya Peserta didik Kelas VII SMP Negeri 27 Padang”. Jurnal Pendidikan Bahasa dan Sastra Indonesia, Vol. 7 No. 3 September 2018; Seri A 39-44. Padang: UNP.

Nurgiyantoro, B. (2018). Teori Pengkajian Fiksi - Burhan Nurgiyantoro - Google Buku: Vol. Digitalisasi.

Prayogo, W. B. (2012). Kajian Tema dan Amanat Legenda-Legenda dari Kabupaten Klaten, Jawa Tengah. Skripsi. Yogyakarta: Fakultas Bahasa dan Seni Universitas Negeri Yogyakarta.

Putri, F. R., Thahar, H. E., \& Arief, E. (2018). Struktur Dan Kebahasaan Teks Cerita Fantasi Karya Peserta didik Kelas VII Smp Pembangunan Laboratorium. Jurnal Pendidikan Bahasa Dan Sastra Indoonesia, Vol. 1 No. 7, 25-32.

Setiyaningsih, I., \& Santhi, M. S. (2019). Bahasa Indonesia : SMP/MTs kelas VII semester 1.

Taum, Yoseph Yapi. (2017). Pembelajaran Sastra Berbasis Teks: Peluang dan Tantangan Kurikulum 2013. Jurnal Ilmiah Kebudayaan SINTESIS. 11(1):12-22. 